\title{
Effect of raw milk on allergic responses in a murine model of gastrointestinal allergy
}

\author{
Alison J. Hodgkinson ${ }^{1 *}$, Natalie A. McDonald ${ }^{1}$ and Brad Hine ${ }^{1,2}$ \\ ${ }^{1}$ Food E Bio-based Products, AgResearch Limited, 10 Bisley Road, PB 3123, Ruakura, Hamilton 3240, New Zealand \\ ${ }^{2}$ CSIRO Animal, Food and Health Sciences, New England Highway, Armidale, NSW, Australia \\ (Submitted 8 November 2013 - Final revision received 7 March 2014-Accepted 18 March 2014 - First published online 29 May 2014)
}

\begin{abstract}
Epidemiological studies have shown an association between the consumption of raw farm milk and reduced incidence of allergy. In the present study, we fed untreated raw milk, gamma-sterilised milk, heat-treated milk or water to mice and compared their responses to allergen exposure and challenge treatment in a mouse model of gastrointestinal allergy. From weaning (3 weeks old), groups of BALB/c female mice $(n)$ ) received raw milk, gamma-sterilised milk, heated milk or water via drink bottles, with the control group receiving water. All mice were fed a standard (dairy protein-free) rodent diet. At 6 and 8 weeks, groups were given intra-peritoneal injections with ovalbumin (OVA)/alum to sensitise them to the antigen. Controls were sham immunised. At week 10, mice were fasted and challenged four times on alternate days by intra-gastric administration with $50 \mathrm{mg}$ OVA or saline. Levels of bacteria and milk proteins were assessed in milk samples. Mouse serum levels of specific IgE, IgG $\operatorname{Ig}_{1}$ and $\operatorname{IgG}_{2 \mathrm{a}}$ antibodies and mouse mast cell protease-1 (MMCP-1) were determined. Cytokine responses to $48 \mathrm{~h}$ activation with OVA were measured in cultured splenocytes from mice. Sterilised and heated milks contained no viable bacteria and reduced detectable levels of many milk proteins, in contrast to raw milk. Mice drinking raw milk had highest serum MMCP-1 and specific-OVA IgE responses. Cultured splenocytes from OVA-primed mice produced similar levels of IL-4 in response to the antigen; however, IL-10 levels were highest from mice drinking raw milk. Overall, the present study adds to the evidence that consuming different types of milk can affect allergic responses to a non-related dietary antigen.
\end{abstract}

Key words: Raw milk: Bovine milk: Food allergy: Hygiene hypothesis

The prevalence of allergy, including asthma, atopic dermatitis, hay fever and allergic sensitisation to food antigens, has increased markedly in Westernised countries in recent decades. The hygiene hypothesis has been proposed, which postulates that the increase in allergic disease is due to a decrease in bacterial exposure as a result of changes in lifestyle $^{(1)}$. We have evolved in a rich microbial environment, and early-life exposure to environmental microbes is important, if not crucial, in the maturation of the immune system. This concept has been well demonstrated in studies using germ-free mice ${ }^{(2,3)}$.

Epidemiological studies have shown an association between the loss of rural living conditions and increased incidence of allergy. Large-scale studies undertaken in European communities have sought to determine which environmental and/or nutritional experience may be protective against the development of allergy ${ }^{(4,5)}$. Population studies, using individuals with a similar genetic background but divergent environmental exposures, have consistently shown that children growing up on a farm are at a significantly lower risk of allergy development ${ }^{(6)}$.

Consumption of farm milk is one factor that has been identified which might contribute to the protective effects ${ }^{(7)}$. A recent study of more than 7000 participants in rural regions of Germany, Austria and Switzerland has compared the consumption of raw untreated farm milk with boiled farm milk and commercially processed milks, both pasteurised and ultra-heat-treated (UHT) milks. Their findings suggested that the protective effect of raw farm milk may be due to the whey protein component of milk.

We undertook the present study to further investigate which components of farm milk probably contribute to protection against the development of allergy. In the present study, we compared untreated raw milk containing bacteria with both gamma-sterilised milk that had had no viable bacteria and heated milk that had no viable bacteria as well as denatured milk proteins. We fed these milks to mice, and compared their responses to allergen exposure and challenge treatment

Abbreviations: IFN- $\boldsymbol{\gamma}$, interferon- $\boldsymbol{\gamma}$; LPS, lipopolysaccharide; MMCP-1, mouse mast cell protease-1; OVA, Ovalbumin; PBS-T, PBS containing $0 \cdot 05 \%$ ( $/ \mathrm{v}$ ) Tween-20; TGF, transforming growth factor. 
using a mouse model of gastrointestinal allergy. Mice were first sensitised to a model of non-milk antigen, ovalbumin (OVA), by intra-peritoneal injection followed by an oral challenge with this antigen. The immune response was assessed by a number of humoral and cellular response measures.

\section{Materials and methods \\ Milk collection and treatment}

Raw bovine milk was collected directly from a dairy farm three times weekly, during the course of the animal trial. At a standard time after the morning milking, milk was collected from the farm vat where the milk had been chilled to $4{ }^{\circ} \mathrm{C}$ and constantly stirred. At each collection, milk was split into two aliquots. Aliquot 1 was stored directly at $4^{\circ} \mathrm{C}$ with no treatment (raw milk). Aliquot 2 was heated to $87^{\circ} \mathrm{C}$ on a hot plate with constant stirring, allowed to cool to room temperature, filtered through sterile surgical gauze to remove the skin formed during the heating process and then stored at $4{ }^{\circ} \mathrm{C}$ (heated milk). At the start of the trial and then every 2 nd week thereafter, a third aliquot of milk was sent to a commercial facility (Schering-Plough) to be gamma irradiated (low dose, 15-17kGy; sterilised milk). Before and following irradiation, milk was transported and stored at $4^{\circ} \mathrm{C}$. All milks were stored at $4^{\circ} \mathrm{C}$ until required for feeding to mice.

\section{Milk analysis}

Following treatments at each milk collection, subsamples of the raw, heated and sterilised milks were collected to assess the levels of bacterial growth. Milk samples $(50 \mu \mathrm{l}$ of each milk sample) were spread on both Columbia Sheep Blood and Esculin Sheep Blood Agar plates (Fort Richard Laboratories Limited). The plates were incubated at $37^{\circ} \mathrm{C}$ and the number of bacterial colonies visually assessed at 24 and $48 \mathrm{~h}$.

Levels of lipopolysaccharide (LPS) were measured in representative milk samples for each treatment type using a kit (Lonza Kinetic-QCL), according to the manufacturer's recommendations, and Soft Max Pro software (VersaMax; Molecular Devices). In addition, LPS levels were also monitored in a representative raw milk sample incubated over a $24 \mathrm{~h}$ period at room temperature (to simulate the condition of milks fed to mice).

Levels of total protein and fat were measured in a subset of milk samples (raw, heated and sterilised) using standard laboratory techniques (AsureQuality). Levels of albumin, $\alpha$-lactalbumin, $\beta$-lactoglobulin, lactoferrin, total IgG, IgA and IgM were measured in milk samples using bovine-specific ELISA kits (Bethyl Laboratories). Levels of transforming growth factor (TGF)- $\beta 2$ were also measured using an ELISA kit (Promega). All assays were undertaken according to the manufacturers' recommended protocols.

To assess changes in the composition of milk proteins due to milk treatments, a subset of milk samples (raw, heated and sterilised) from the same batch of milk were evaluated by gel electrophoresis, based on published SDS-PAGE methods ${ }^{(8)}$ with some modifications. The samples were diluted to the same protein concentration and then prepared in Laemmli's buffer containing $\beta$-mercaptoethanol (5\%) and boiled for $5 \mathrm{~min}$. Separation was performed using a $12.5 \%$ Tris-glycine polyacrylamide gel (Criterion; Bio-Rad Laboratories). Equal amounts of protein were loaded into the gel and run for $60 \mathrm{~min}$ at a constant voltage $(150 \mathrm{~V})$, and then stained by the colloidal Coomassie Brilliant Blue G-250 $\operatorname{method}^{(9)}$.

\section{Mice and experimental protocol}

Animal experiments were performed in accordance with the guidelines of the New Zealand National Animal Ethics Advisory Committee for the use of animals in research, testing and teaching. All experimental procedures were approved by the Ruakura Animal Ethics Committee. BALB/c mice used in the present study were housed in specific pathogen-free conditions and fed ad libitum on a dairy protein-free diet (AIN-93G Modified Rodent Diet with Soy Protein and Lactose; Research Diets, Inc.). At weaning (3 weeks of age), female mice were randomly allocated to five groups ( $n$ 8) and further supplied ad libitum with either raw milk, gamma-sterilised milk, heated milk or water via drink bottles, with the control group receiving water. Liquids were changed daily with fresh chilled aliquots. Mice were weighed weekly to monitor their general health. At 6 and 8 weeks of age, groups received intra-peritoneal injections containing 0 (control group) or $50 \mu \mathrm{g}$ OVA (water and all milk groups) (OVA, A5503 grade $\mathrm{V}$; Sigma-Aldrich) with $1.5 \mathrm{mg}$ alum (Imject Alum; Thermo Fisher Scientific). At 10 weeks of age, mice were fasted overnight and then challenged once daily on four alternate days with 0 (control group) or $50 \mathrm{mg}$ OVA (water and all milk groups) in $200 \mu \mathrm{l}$ saline solution by oral administration. Mice were monitored for $2 \mathrm{~h}$ following oral administration to assess hypersensitivity responses, which were scored using a modified reporting system ${ }^{(10)}: 1$ - smooth coat, bright-eyed and alert, no symptoms; 2 - active, bright-eyed, slightly hunched and jumpy, scratching and rubbing around nose and head; 3 - not as alert or active, hunched when sitting and eyes closed or squinting, fur slightly ruffled; 4 hunched and still, little interest in the environment, fur noticeably ruffled; 5 - non-reactive to stimuli, fur bottle-brush appearance, cold to touch. Mice were also observed for signs of diarrhoea. At $2 \mathrm{~h}$ after the fourth and final oral administrations, mice were euthanised by $\mathrm{CO}_{2}$ asphyxiation and cervical dislocation. Heparinised blood was obtained by cardiac puncture, stored on ice and then centrifuged at $1650 \mathrm{~g}$ for $10 \mathrm{~min}$ at room temperature. Plasma was collected from all mice and stored at $-20^{\circ} \mathrm{C}$ until analysed for levels of OVA-specific $\operatorname{IgG}_{1}, \operatorname{IgG}_{2 \mathrm{a}}$ and IgE and mouse mast cell protease-1 (MMCP-1). Spleen from individual mice was excised and cells isolated for culture as detailed below.

\section{Mouse mast cell protease-1 measurement}

MMCP-1 levels in murine plasma were measured using murine-specific ELISA kits (88-7503-86; eBioscience), according to the manufacturer's recommended protocols. 


\section{Ovalbumin-specific antibody measurement}

OVA-specific antibody titres were measured using a noncompetitive indirect ELISA protocol based on previously described methods ${ }^{(11,12)}$. Plate washes were carried out by an automated plate washer (AM60 MRW; Dynex Technologies Inc.) using PBS containing 0.05\% (v/v) Tween-20 (PBS-T), all samples and reagents ( $100 \mu \mathrm{l}$, unless otherwise stated) were diluted in PBS-T containing $1 \%(\mathrm{w} / \mathrm{v})$ bovine serum albumin (A-7906; Sigma-Aldrich) and all incubations were conducted at room temperature, unless otherwise stated. Microtitre plates (Maxisorb F-96; Nalge Nunc International) were incubated overnight at $4{ }^{\circ} \mathrm{C}$ with OVA $(10 \mu \mathrm{g} / \mathrm{ml})$ in bicarbonate buffer (50 mm-NaHCO $3, \mathrm{pH}$ 9.8). After washing, plates were incubated with $250 \mu \mathrm{l}$ PBS-T containing $1 \%(\mathrm{w} / \mathrm{v})$ bovine serum albumin for $1 \mathrm{~h}$, and then washed. Serial dilutions of the test samples $(1: 100,1: 1000,1: 10000$ and $1: 100000 ; 100 \mu 1)$ were then added, incubated for $1 \mathrm{~h}$ and then washed three times. Positive (plasma pooled from mice orally administered with OVA) and negative (untreated mouse plasma) controls were run on each plate with the sample dilutions. Goat anti-mouse $\operatorname{IgE}, \operatorname{IgG}_{1}$ or $\operatorname{IgG}_{2 \mathrm{a}}$ conjugated with horseradish peroxidase (Bethyl Laboratories) were added to the plates at 1:1000, 1:200 000 and 1:5000 dilutions, respectively, and then incubated for $1 \mathrm{~h}$. After washing, the plates were incubated with substrate solution (TMB One Component HRP Microwell substrate; BioFX Laboratories) for $20 \mathrm{~min}$ and then the reaction was stopped with $50 \mu \mathrm{l}$ of $2 \mathrm{M}-\mathrm{H}_{2} \mathrm{SO}_{4}$. Optical density was measured at $450 \mathrm{~nm}$ using an automated plate reader (VersaMax; Molecular Devices). Antibody titres for the test samples were defined as the reciprocal of test sample dilution that produced an optical density equal to $50 \%$ of the maximum optical density above the background of the positive control. Results are expressed as titre units of antibody.

\section{Splenocyte culture and cytokine measurement}

A cellular suspension was produced by homogenising individual spleens using the gentle MACS Dissociator (Miltenyi Biotec). Erythrocytes were lysed using ACK Lysing Solution ${ }^{\text {(13) }}$ (Thermo Fisher Scientific Inc.) and the splenocytes extensively washed and resuspended in Roswell Park Memorial Institute (RPMI)-1640 medium containing $10 \%(\mathrm{v} / \mathrm{v})$ fetal calf serum, 100 units penicil$\mathrm{lin} / \mathrm{ml}, \quad 100 \mu \mathrm{g}$ streptomycin $/ \mathrm{ml}$ and $2 \mathrm{~mm}$-glutamine. Cells $\left(5 \times 10^{6}\right.$ cells $\left./ \mathrm{ml}\right)$ were co-cultured in twenty-four-well plates at $37^{\circ} \mathrm{C}$ in $5 \% \mathrm{CO}_{2}$, and stimulated with OVA $(100 \mu \mathrm{g} / \mathrm{ml})$. Cells stimulated with concanavalin A ( $1 \mu \mathrm{g} / \mathrm{ml})$ and LPS $(2 \mu \mathrm{g} / \mathrm{ml})$ were used for positive controls and unstimulated cells for background controls. Supernatants were harvested at $48 \mathrm{~h}$ and levels of IL-4, IL10 and interferon- $\boldsymbol{\gamma}$ (IFN- $\boldsymbol{\gamma}$ ) were measured using ELISA kits (OptEIA mouse ELISA set; BD), according to the manufacturer's recommendations. Detection limits for each assay were $7 \cdot 8,31 \cdot 3$ and $31.3 \mathrm{pg} / \mathrm{ml}$ for IL-4, IL-10 and IFN- $\boldsymbol{\gamma}$, respectively.

\section{Statistical analysis}

Data for mouse weight gain and milk proteins are presented as means with their standard errors. Measurements of blood responses and cytokine levels in splenocytes were log transformed (to stabilise the variance) and then analysed by treatment, using ANOVA in GenStat (GenStat for Windows 16th Edition; VSN International). Geometric means of the treatment groups are graphed with the corresponding standard errors of means. Means were compared using least significant differences.

\section{Results}

\section{Milk analyses}

Columbia Sheep Blood Agar plates were used as a general medium to grow a broad range of aerobic Gram-negative and Gram-positive bacteria, including, Enterobacteriaceae, Pseudomonas, streptococci, enterococci and staphylococci. Esculin Sheep Blood Agar plates were used to isolate the members of the genus Enterococcus. Visual assessment of bacterial colony numbers in milk samples showed that heat and gamma sterilisation treatments killed all viable bacteria. All raw milk samples had grown colonies by $24 \mathrm{~h}$, with an increase in the number of colonies after $48 \mathrm{~h}$, but no identification of bacteria was carried out. LPS levels in raw milk samples were low (approximately 0.03 endotoxin units $/ \mathrm{ml}$ ). However, a representative raw milk sample incubated at room temperature showed a rise in LPS levels to 1.2 endotoxin units/ml between 16 and $24 \mathrm{~h}$.

Levels of total protein were similar for the three types of milk: $33.5,34.2$ and $33.6 \mathrm{mg} / \mathrm{ml}$ for the raw, heated and sterilised milks, respectively. Levels of total fat were $18 \%$ lower in the heated milk compared with the raw and sterilised milks, probably due to the procedure of filtering the heated milk following the heating step. Levels of total fat were 43.9, $34 \cdot 2$ and $43.8 \mathrm{mg} / \mathrm{ml}$ for the raw, heated and sterilised milks, respectively.

Analysis of milk proteins by ELISA showed that the heated milk had markedly reduced levels of some proteins compared with the raw milk; levels of albumin, lactoferrin, total IgG, IgA and IgM were not detectable in the heated milk (Table 1). Interestingly, TGF- $\beta$ was least affected by heating, with levels reduced by $36 \%$ compared with the levels of the raw milk. The gamma-sterilised milk also had lower levels of proteins compared with the raw milk, ranging from a $4 \%$ reduction for $\operatorname{IgG}$ to $52 \%$ for lactoferrin (Table 1). Assessment of milks by SDS-PAGE indicated that the heated and raw milks were similar in their protein profile; however, there appeared to be changes in the number of protein bands and visible evidence of some band smearing in the sterilised milk (Fig. 1).

\section{Mouse health and well-being}

The weights of mice were monitored to assess their general health. Similar weight gains were observed for mice in all the treatment groups. During the study period, the mean body-weight gain for all groups was 8.15 (SEM 0.57) g. Although mice fed milk were potentially given access to a 
higher-energy diet, those mice drinking milk showed no difference in weight gain compared with mice drinking water.

\section{Oral allergen-induced responses}

Observational data of the responses to the oral challenge were collected at intervals of $10 \mathrm{~min}$ over the first hour, then again at $2 \mathrm{~h}$, for each of the four oral administrations (data not shown). In mice presensitised with OVA, the oral challenge with this protein induced increasing severity of physical symptoms with increasing numbers of oral administration. The pattern of responses varied with individual mice; some mice reacted quickly while others reacted more slowly, and the recovery time also varied with individual mice. The severity of symptoms ranged from 1 to 4 , with higher scores observed for OVA-treated mice that were drinking the raw milk, compared with the other groups. At no time was diarrhoea induced in any of the mice, even with the fourth and final oral administrations. Control mice (non-sensitised) displayed no adverse physical reactions.

\section{Induction of mouse mast cell responses}

Multiple oral administrations with OVA in mice presensitised with OVA produced a very large increase in serum levels of MMCP-1 compared with control mice (Fig. 2). The levels of MMCP-1 were 2-fold higher $(P<0.05)$ in mice drinking the raw milk compared with those drinking water, and 3-fold higher in mice drinking the raw milk compared with those drinking the heated or sterilised milk. There were no differences in the levels of MMCP-1 when comparing OVA-treated mice drinking the heated milk, sterilised milk or water.

\section{Antibody responses to ovalbumin}

OVA-specific IgE titres were higher in mice presensitised and challenged with OVA compared with control mice (Fig. 3(A)). Furthermore, there were differences in OVA-specific IgE titres between the groups depending on their diet. Mice drinking the heated milk had lower levels of OVA-specific IgE compared with those drinking the raw milk. A trend was observed, suggesting that mice drinking the raw milk had higher levels of OVA-specific IgE compared with those drinking the sterilised milk and water. All groups of mice presensitised and challenged with OVA had similar levels of OVA-specific $\mathrm{IgG}_{1}$, with levels in all these groups being higher than those in control mice (Fig. 3(B)). For OVA-specific $\operatorname{IgG}_{2 \mathrm{a}}$, only mice drinking the raw milk had titres higher than control

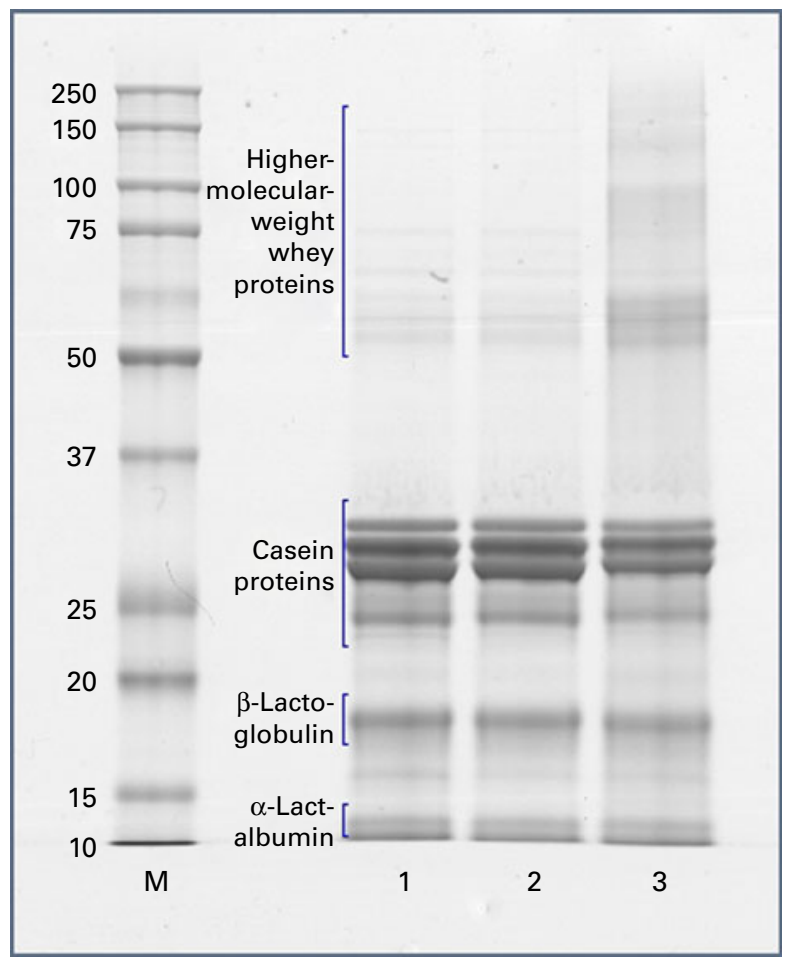

Fig. 1. SDS-PAGE characterisation of milk samples. To assess the changes in the composition of milk proteins induced by milk treatments, representative samples of raw milk (lane 1), heated milk (lane 2) and sterilised milk (lane 3), all collected from a dairy farm on the same day, were run on SDS-PAGE and visualised with Coomassie Blue stain. Molecular-weight markers (kDa) were run alongside (lane $\mathrm{M}$ ). (A colour version of this figure can be found online at http://www.journals.cambridge.org/bjn) 


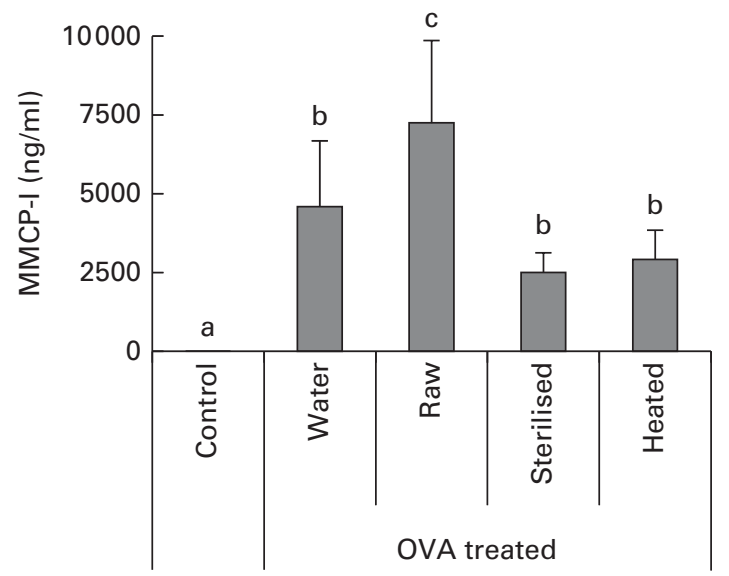

Fig. 2. Plasma levels of mouse mast cell protease-1 (MMCP-1). Mice presensitised with $50 \mu \mathrm{g}$ ovalbumin (OVA) by intra-peritoneal injections were then challenged four times with $50 \mathrm{mg}$ OVA. Non-sensitised control mice were challenged with saline. Plasma was collected from all mice $(n 8$ per group) $2 \mathrm{~h}$ after the last challenge. MMCP-1 levels were measured using ELISA kits. Values are geometric means, with their standard errors represented by vertical bars. ${ }^{a, b, c}$ Mean values with unlike letters were significantly different $(P<0.05 ;$ ANOVA $)$.

mice, although these levels were not different compared with the other groups presensitised and challenged with OVA (Fig. 3(C)).

\section{Induction of cytokine secretion in splenocytes by ovalbumin}

Culture supernatants from cells isolated from individual mouse spleen samples were analysed for the levels of IFN- $\gamma$, IL-4 and IL-10. In vitro restimulation with OVA induced minimal IL-4 and IL-10 responses in splenocytes from control mice (Fig. 4(A) and (B), respectively). In contrast, when splenocytes from OVA-presensitised and orally challenged mice were restimulated with OVA, the levels of IL- 4 and IL-10 were 8- to 14-fold higher compared with control mice. The highest levels of IL- 4 were induced in splenocytes from mice drinking the water, raw or heated milk; the levels were $30-45 \%$ higher in splenocytes from these mice compared with those from mice drinking the sterilised milk. Interestingly, the highest levels of IL-10 were induced in splenocytes from mice drinking the raw milk; the levels were 40-45\% higher in splenocytes from these mice compared with those from mice drinking the water, sterilised or heated milk. In contrast to IL- 4 and IL-10, IFN- $\gamma$ levels were found to be highest in OVA-restimulated splenocyte cultures from control mice. When splenocytes from OVA-presensitised and orally challenged mice were restimulated with OVA, IFN- $\gamma$ levels were found to be similar for all the groups and approximately $60 \%$ lower compared with control mice (Fig. 4(C)).

\section{Discussion}

There is an increasing body of knowledge that associates a reduction in childhood asthma and allergies with consumption of farm milk, independent of concurrent farm exposure ${ }^{(14)}$. In a murine model of gastrointestinal allergy, we have demonstrated that drinking milks exposed to different treatments (raw untreated, gamma-sterilised or heat-treated) changed the allergic responses to a non-related dietary antigen, OVA. We found that the group fed the raw milk had a greater allergic response than those fed the sterilised milk,
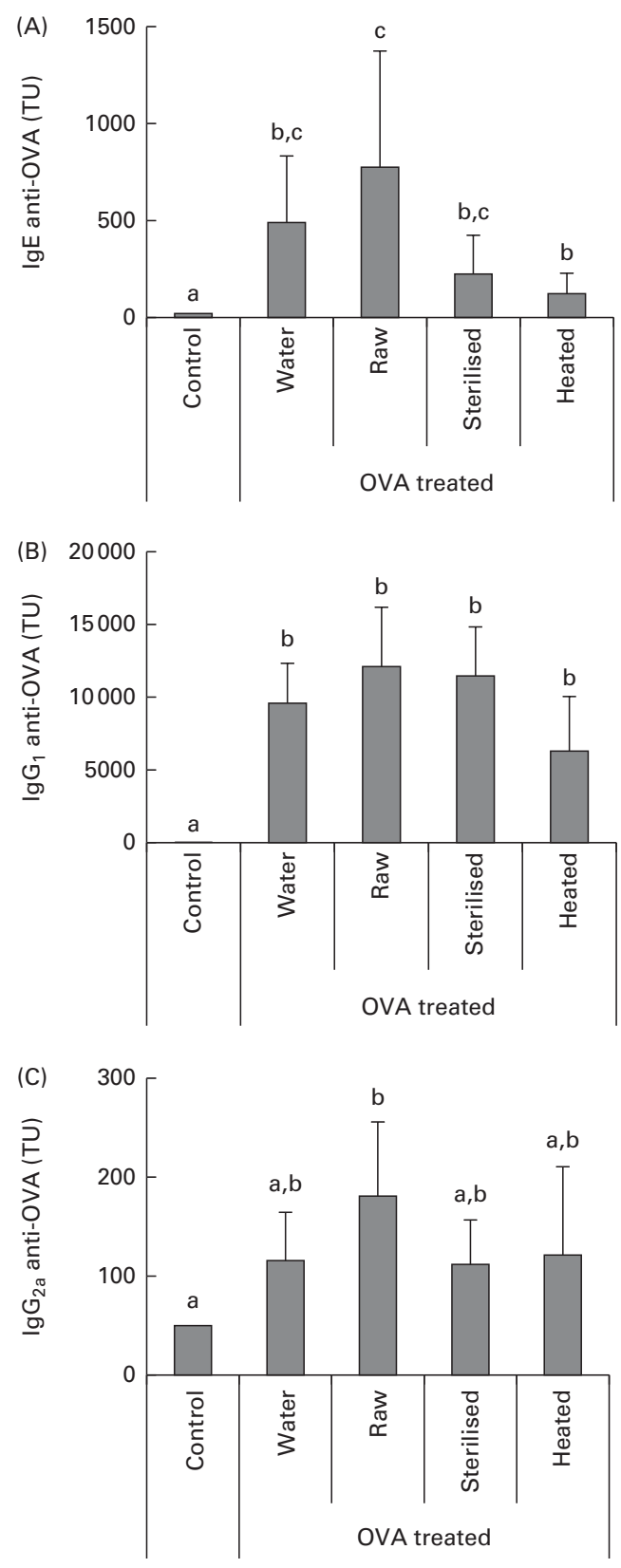

Fig. 3. Plasma levels of ovalbumin (OVA)-specific (A) $\lg E$, (B) $\lg _{1}$ and (C) $\operatorname{lgG}_{2 a}$. Mice presensitised with OVA by intra-peritoneal injections were then challenged four times with $50 \mathrm{mg}$ OVA. Non-sensitised control mice were challenged with saline. Plasma was collected from all mice ( $n 8$ per group) $2 \mathrm{~h}$ after the last challenge. Levels of OVA-specific antibodies were measured using ELISA kits. Values are geometric means of arbitrary titre units (TU), with their standard errors represented by vertical bars. ${ }^{a, b, c}$ Mean values with unlike letters were significantly different $(P<0.05$; ANOVA). 

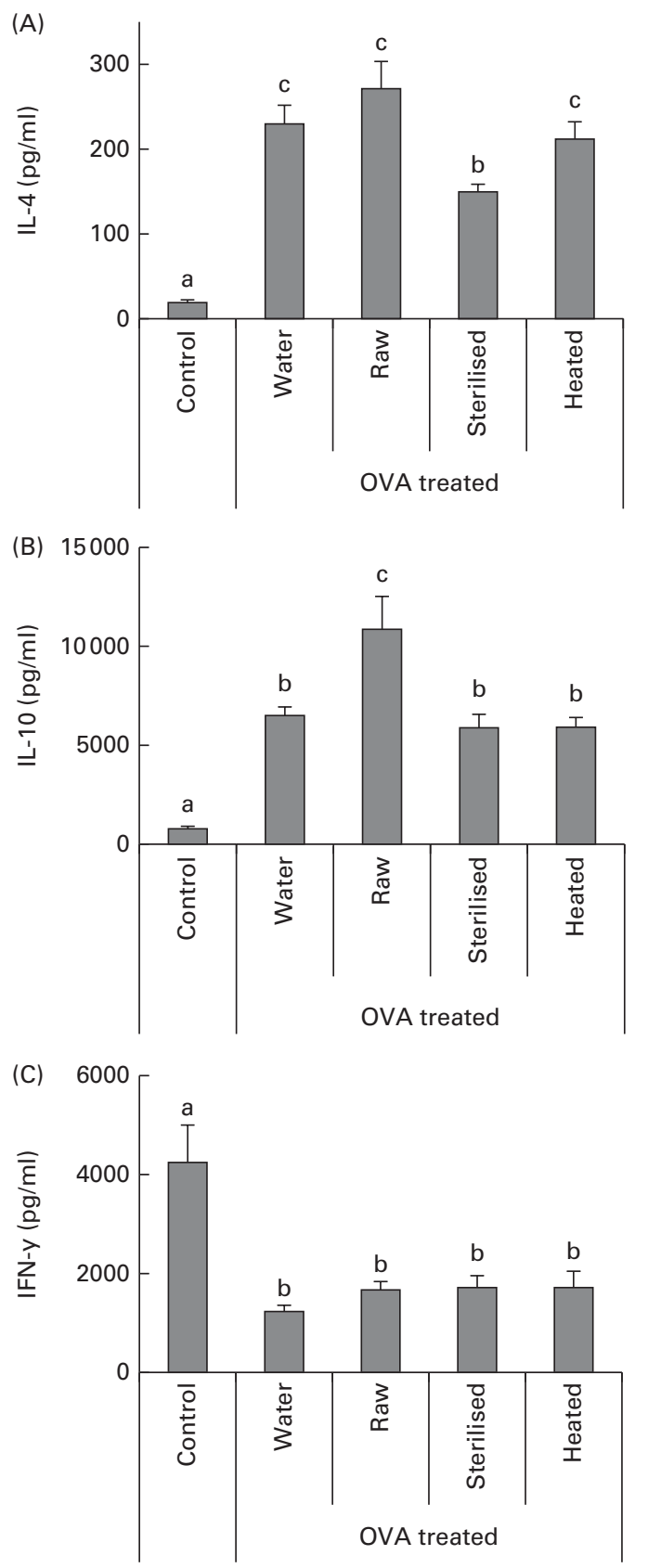

Fig. 4. Culture supernatant levels of (A) IL-4, (B) IL-10 and (C) interferon- $\gamma$ (IFN- $\gamma$ ). Mice presensitised with ovalbumin (OVA) by intra-peritoneal injections were then challenged four times with $50 \mathrm{mg}$ OVA. Non-sensitised control mice were challenged with saline. Spleen was collected from each mouse ( $n 8$ per group) immediately after killing, $2 \mathrm{~h}$ after the last challenge. Isolated spleen cells from individual mice were cultured in the presence of OVA $(100 \mu \mathrm{g} / \mathrm{ml})$ for $48 \mathrm{~h}$. Cytokine levels in supernatants were measured using ELISA kits. Values are geometric means, with their standard errors represented by vertical bars. ${ }^{\mathrm{a}, \mathrm{b}, \mathrm{c}}$ Mean values with unlike letters were significantly different $(P<0.05$; ANOVA).

heated milk or water as measured by the levels of MMCP-1 and specific IgE antibody. Furthermore, in splenocytes harvested from the different groups, we observed differential cytokine responses when the cells were re-exposed to the antigen.
In the present study, the raw milk contained substantial levels of viable bacteria compared with the sterilised and heated milks; the levels of LPS were low in the chilled raw milk, although they rose after a time at room temperature. A study measuring endotoxin levels in farm milk has shown that LPS levels in untreated milks were similar to or even lower than those in commercial milks; the difference is thought to be due to storage factors and freshness of milks ${ }^{(15)}$. Paradoxically, endotoxins have been shown to both protect against and exacerbate allergic responses. On the one hand, it can act as a primer or adjuvant, and augment asthma or atopic inflammation ${ }^{(16)}$. On the other hand, signalling by intestinal microbes via LPS and Toll-like receptor- 4 can reduce allergic responses as demonstrated by the higher susceptibility to food allergy in mice lacking a functional Toll-like receptor- $4^{(17)}$. Epidemiological studies have shown that early-life exposure to environmental microbes had a strong effect on the expression of Toll-like receptors with a continued increase in expression with additional microbial exposure through childhood ${ }^{(18)}$. Oral ingestion of milkderived bacteria could theoretically result in the colonisation of these micro-organisms in the gastrointestinal tract; however, in the present study, we did not analyse the microbiota to establish this hypothesis. Studies have shown that the commensal microbiota are established in early life and that they largely reflect the commensal population of the mother ${ }^{(19)}$ Later consumption of dietary bacteria (probiotic) does not appear to readily induce the establishment of the microbiota $^{(20)}$. In the present study, mice were introduced to different milks at weaning and maintained on this regimen throughout the study; therefore, the live bacteria contained in the raw milk were present during the course of the treatments and may have influenced the allergy outcome.

The protective effect of raw milk has been attributed to the presence of non-denatured bioactive Ig and other immunomodulatory proteins such as lactoferrin, TGF- $\beta$ and IL- $10^{(21)}$. We showed that gamma sterilisation induced some modification to milk proteins as illustrated by the different banding patterns in SDS-PAGE gels, suggesting a change in the integrity of milk proteins. Nonetheless, the dominant whey proteins in the sterilised milk were still bound by their specific antibodies in immunoassays, suggesting that the three-dimensional structure and, therefore, antigen recognition of these proteins was probably not appreciably changed. The measurable levels of some proteins detected by ELISA were reduced by irradiating the milks; IgA and the cytokine TGF- $\beta$ were the most affected, with their detectable levels being reduced by 40 and $48 \%$, respectively. Conversely, IgG, IgM and $\beta$-lactoglobulin were largely unaffected by irradiation. Heat-treating milks, by heating up to $87^{\circ} \mathrm{C}$, was obviously a much harsher process, illustrated by the denaturation of many of the milk proteins, as assessed by their capacity to be bound by a specific antibody. All Ig isotypes in the heated milk were undetectable by ELISA, and the measurable levels of other whey proteins, including $\beta$-lactoglobulin, $\alpha$-lactalbumin and albumin, were also severely reduced by the heat treatment compared with their levels in the raw milk. It is interesting to note that of all the proteins measured, 
TGF- $\beta$ was least affected by the heat treatment with levels in the heated milk similar to those in the sterilised milk. However, although there were marked differences in the denaturation of milk proteins between the sterilised and heated milks, there were only small differences in the allergic responses of mice drinking these two milks.

Heating milks is an accepted commercial practice to make milks safe for consumption and to increase their shelf life. Pasteurisation, either at $72^{\circ} \mathrm{C}$ for $15 \mathrm{~s}$ (high heat, shorter time) or at $65^{\circ} \mathrm{C}$ for $5 \mathrm{~min}$ (low heat, longer time), is a standard treatment of milk and extends the shelf life of milk for up to 2 weeks at $4^{\circ} \mathrm{C}$. UHT milk is treated at a very high temperature $\left(120^{\circ} \mathrm{C}\right)$ for $2-3 \mathrm{~s}$, and allows the milk to be stored unopened for very long time periods (up to 9 months) at room temperature. In the present study, the heat-treated milk was heated up to $87^{\circ} \mathrm{C}$ while stirring on a hot plate and then placed in a refrigerator to cool. This treatment replicated the reported process used by farming people, if they were heat treating their milk before consumption ${ }^{(7)}$, and it would be most similar to the UHT type treatment, as the milk was heated for an extended period of time at high heat.

Higher heat and longer treatment times are expected to increase the modification to the milk proteins. The most common effect of heat on milk proteins is the formation of glycation products ${ }^{(22)}$. Milk is the ideal matrix for Maillard reactions, due to its high content of protein and lactose ${ }^{(23)}$. Heat treatment also causes proteins to cross-link with one another, along with causing oxidation reactions including lipid oxidation ${ }^{(24)}$. All of these factors will result in a milk product that has a different composition from that of the raw milk. These changes may have an impact on the allergenicity of milk proteins ${ }^{(25)}$. However, this does not explain why drinking differently treated milks would change the allergic responses to a non-milk protein, as shown in the present study, in which the allergic responses to OVA were influenced by the type of milk in the diet.

Interestingly, it was observed that mice appeared to like drinking milk especially when it was fresh, as these mice would rush up to drink the new milk when it was introduced to the cage. Mice drinking water did not behave in this manner when fresh water was introduced. On the days that mice were fasted overnight before the oral challenge treatment, water was supplied instead of milk. Mice normally given milk ran up to drink, but after tasting the water, they stopped drinking and moved away before coming back and repeating the process several times. This suggested that their behaviour of rushing up when a new bottle was introduced was not because they were overly thirsty and that they had very obviously noticed the change in the liquid supplied in the drink bottles.

The murine model of gastrointestinal allergy used in the present study was developed using OVA antigen ${ }^{(26)}$. OVA/ alum-presensitised mice subsequently exposed to repeated doses of intra-gastric OVA exhibited a dose-dependent allergic response illustrated by gastrointestinal anaphylaxis, with symptoms of diarrhoea usually occurring within $30 \mathrm{~min}$ of exposure to the fourth dose. In the present study, we used similar conditions and observed that there was no symptoms of diarrhoea occurring in any of the mice, even in those that exhibited adverse physical symptoms. In the Brandt model, induction of diarrhoea was dependent on the number of challenges ${ }^{(26)}$, suggesting that in the present study, diarrhoea could have been induced with a greater number of challenges. However, the challenge treatment in the present study did induce differential effects as determined by both serum MMCP-1 and specific OVA antibody responses in mice and antigen-induced cytokine responses in splenocytes.

Mice fed the raw milk had higher MMCP-1 and specific antigen IgE responses than those fed the water, heated milk or sterilised milk. This finding was unexpected. Epidemiological studies have suggested that drinking raw milk reduces allergy manifestation $^{(6)}$. In addition, we found that splenocytes from mice fed the raw milk also produced higher levels of IL-4 than those from the controls, although in this case, the response of mice fed the raw milk was similar to that of mice fed the heated milk, sterilised milk or water. IL-4, a cytokine produced by T-helper type $2 \mathrm{~T}^{\mathrm{T}}$-cells ${ }^{(27)}$, plays a central role in the allergic process, inducing the production of $\operatorname{IgE}$ and the differentiation and expansion of T-helper type 2 T-cells in an autocrine fashion ${ }^{(28)}$. While the sensitised and challenged groups all had similar elevated levels of IL-4, splenocytes from the group drinking the raw milk produced significantly higher levels of the regulatory cytokine IL-10. This cytokine plays an important role in suppressing inflammatory-type immune responses including allergy ${ }^{(29,30)}$. So while mice drinking the raw milk reacted with a higher overall allergic response in vivo, they also produced a greater regulatory response upon restimulation of their cells with the antigen in vitro.

There were significant differences identified between the raw and treated milks in the present study. Bacteria were killed by both gamma sterilisation and heat treatments, and many other changes also occurred in milk components when they underwent their different treatments, with protein denaturation most evident in the heated milk. That there was little difference between the allergic responses of the groups fed the heated and sterilised milks may suggest that protein denaturation did not contribute to the differential responses observed in the present study. These data are in contrast to the conclusions drawn by Loss et al. ${ }^{(7)}$, suggesting that the protective effect of raw milk correlated with the presence of non-denatured whey proteins and that there was no association with viable bacteria. However, more work is needed to fully understand the role of milk components in differential allergic responses.

We have shown a change in allergic responses that is dependent on whether the diet contained raw milk or treated milks. Overall, the present study adds to the evidence that consuming different types of milk can affect allergic responses to a non-related dietary antigen.

\section{Acknowledgements}

The present study was supported by a grant from the New Zealand Ministry of Business, Innovation and Employment (formerly Foundation of Research Science and Technology), 
Contract C10X0806. The funder had no role in the design, analysis or writing of this article.

We thank Laura Kivits, Olivia Wallace and Daralyn Hurford for their expert assistance in cell culture and laboratory analyses, Bobby Smith for his expert assistance with the animal experiments and Harold Henderson for his expert assistance with the statistical analysis.

The authors' contributions are as follows: A. J. H. and B. H. conceptualised and designed the study; N. A. M. and B. H. conducted the experiments; A. J. H. and B. H. analysed and interpreted the data; A. J. H. wrote the first draft of the manuscript. All authors critically reviewed the manuscript and approved the final content.

None of the authors had a personal or professional conflict of interest.

\section{References}

1. Yazdanbakhsh M, Kremsner PG \& van Ree R (2002) Allergy, parasites, and the hygiene hypothesis. Science 296, 490-494.

2. Macpherson AJ \& Harris NL (2004) Interactions between commensal intestinal bacteria and the immune system. Nat Rev Immunol 4, 478-485.

3. Chung H, Pamp SJ, Hill JA, et al. (2012) Gut immune maturation depends on colonization with a host-specific microbiota. Cell 149, 1578-1593.

4. Pfefferle PI, Buchele G, Blumer N, et al. (2010) Cord blood cytokines are modulated by maternal farming activities and consumption of farm dairy products during pregnancy: the PASTURE Study. J Allergy Clin Immunol 125, 108-115.e101-e103.

5. Genuneit J, Buchele G, Waser M, et al. (2011) The GABRIEL Advanced Surveys: study design, participation and evaluation of bias. Paediatr Perinat Epidemiol 25, 436-447.

6. von Mutius E \& Vercelli D (2010) Farm living: effects on childhood asthma and allergy. Nat Rev 10, 861-868.

7. Loss G, Apprich S, Waser M, et al. (2011) The protective effect of farm milk consumption on childhood asthma and atopy: the GABRIELA study. I Allergy Clin Immunol 128, 766-773.e 764 .

8. Laemmli UK (1970) Cleavage of structural proteins during the assembly of the head of bacteriophage T4. Nature $\mathbf{2 2 7}$, 680-685.

9. Neuhoff V, Arold N, Taube D, et al. (1988) Improved staining of proteins in polyacrylamide gels including isoelectric focusing gels with clear background at nanogram sensitivity using Coomassie Brilliant Blue G-250 and R-250. Electrophoresis 9, 255-262.

10. Gill HS, Shu Q, Lin H, et al. (2001) Protection against translocating Salmonella typhimurium infection in mice by feeding the immuno-enhancing probiotic Lactobacillus rhamnosus strain HN001. Med Microbiol Immunol 190 , 97-104.

11. Clark BR \& Engvall E (1980) Enzyme-linked immunosorbent assay (ELISA): theoretical and practical aspects. In Enzymeimmunoassay, pp. 167-180 [ET Maggio, editor]. Boca Raton, FL: CRC Press.
12. Hodgkinson AJ, McQuoid MR \& Hodgkinson SC (1995) Antibody class-specific immune responses in ovine milk measured by ELISA. Proc N Z Soc Anim Prod 55, 218-220.

13. Bossuyt X, Marti GE \& Fleisher TA (1997) Comparative analysis of whole blood lysis methods for flow cytometry. Cytometry 30, 124-133.

14. Braun-Fahrlander C \& von Mutius E (2011) Can farm milk consumption prevent allergic diseases? Clin Exp Allergy $\mathbf{4 1}$, 29-35.

15. Gehring U, Spithoven J, Schmid S, et al. (2008) Endotoxin levels in cow's milk samples from farming and non-farming families - the PASTURE study. Environ Int 34, 1132-1136.

16. Liu AH (2002) Endotoxin exposure in allergy and asthma: reconciling a paradox. J Allergy Clin Immunol 109, 379-392.

17. Bashir ME, Louie S, Shi HN, et al. (2004) Toll-like receptor 4 signaling by intestinal microbes influences susceptibility to food allergy. J Immunol 172, 6978-6987.

18. Loss G, Bitter S, Wohlgensinger J, et al. (2012) Prenatal and early-life exposures alter expression of innate immunity genes: the PASTURE cohort study. J Allergy Clin Immunol 130, 523-530.e 529 .

19. Tannock GW (2007) What immunologists should know about bacterial communities of the human bowel. Semin Immunol 19, 94-105.

20. Mah KW, Chin VI, Wong WS, et al. (2007) Effect of a milk formula containing probiotics on the fecal microbiota of Asian infants at risk of atopic diseases. Pediatr Res 62, 674-679.

21. van Neerven RJ, Knol EF, Heck JM, et al. (2012) Which factors in raw cow's milk contribute to protection against allergies? J Allergy Clin Immunol 130, 853-858.

22. Pischetsrieder $M$ \& Henle $T$ (2012) Glycation products in infant formulas: chemical, analytical and physiological aspects. Amino Acids 42, 1111-1118.

23. Meltretter J \& Pischetsrieder M (2008) Application of mass spectrometry for the detection of glycation and oxidation products in milk proteins. Ann N Y Acad Sci 1126, 134-140.

24. Lima M, Assar SH \& Ames JM (2010) Formation of N(epsilon)-(carboxymethyl)lysine and loss of lysine in casein glucose-fatty acid model systems. J Agric Food Chem 58, 1954-1958.

25. Nowak-Wegrzyn A, Bloom KA, Sicherer SH, et al. (2008) Tolerance to extensively heated milk in children with cow's milk allergy. J Allergy Clin Immunol 122, 342-347, 347.e341-e342.

26. Brandt EB, Strait RT, Hershko D, et al. (2003) Mast cells are required for experimental oral allergen-induced diarrhea. J Clin Invest 112, 1666-1677.

27. Mosmann TR, Cherwinski H, Bond MW, et al. (1986) Two types of murine helper $\mathrm{T}$ cell clone. I. Definition according to profiles of lymphokine activities and secreted proteins. J Immunol 136, 2348-2357.

28. Mosmann TR \& Sad S (1996) The expanding universe of T-cell subsets: Th1, Th2 and more. Immunol Today 17, 138-146.

29. Marcelletti JF \& Katz DH (1996) IL-10 stimulates murine antigen-driven antibody responses in vitro by regulating helper cell subset participation. Cell Immunol 167, 86-98.

30. Robinson DS, Larche M \& Durham SR (2004) Tregs and allergic disease. J Clin Invest 114, 1389-1397. 